Revista de Biología Marina y Oceanografía

Vol. 51, №3: 629-641, diciembre 2016

DOI 10.4067/S0718-19572016000300014

ARTICLE

\title{
The California lobster fishery and climate in the kelp bed ecosystem
}

\author{
Pesquería de la langosta roja y el clima en el \\ ecosistema de bosques de macroalgas
}

\begin{abstract}
Alejandra Chávez-Hidalgo ${ }^{1 *}$ and Ernesto A. Chávez ${ }^{1}$
${ }^{1}$ Centro Interdisciplinario de Ciencias Marinas, Instituto Politécnico Nacional, Av. IPN s/n, Col. Sta Rita, Playa El Conchalito, La Paz, B.C.S., 23096, México."achavezh@gmail.com

Resumen.- Poblaciones explotadas en la costa oeste de la península de Baja California ocupan hábitats complejos de arrecifes rocosos que se caracterizan por su elevada diversidad de especies de algas que conforman estos bosques de macroalgas. En esta zona se desarrolla una intensa actividad pesquera, induciendo cambios en la estructura de la comunidad bentónica, deterioro del hábitat y reducción de la biomasa de especies de alto valor comercial como la langosta roja (Panulirus interruptus). El impacto del clima fue explorado y se encontró una correlación baja pero significativa entre el Índice de Oscilación del Sur con el número de reclutas de un año de edad y con el número de adultos. La pesquería de langosta en esta zona, contribuye con el $85-92 \%$ de la captura total de la costa Pacífico de la península. Se exploró una evaluación actualizada de la población que incluyó distintas estrategias óptimas de pesca con variables socio-económicas, mediante un modelo de simulación bajo 3 posibles escenarios como objetivos de gestión. Las estrategias de pesca fueron simuladas cambiando la mortalidad por pesca y la edad de primera captura. Se espera que estos resultados sirvan de base para proponer estrategias de gestión de la pesca de la langosta en el área de estudio.
\end{abstract}

Palabras clave: Costa rocosa, langosta roja, Baja California, evaluación de la población, simulación

Abstract.- Exploited stocks of the west coast of the Baja California peninsula inhabit in a complex habitat of rocky reefs characterized by high diversity of seaweeds in the kelp forest. In these fishing grounds, there is intense fishing activity, inducing changes in the structure of the benthic community, such as habitat deterioration and biomass reduction of species with high commercial value such as the California spiny lobster (Panulirus interruptus). The impact of climate was explored and a low but significant correlation between the Southern Oscillation Index and the one-year-old recruits and with the number of adults was found. The lobster fishery of this area extracts $85-92 \%$ of the total catch of the Pacific coast of the peninsula. An updated stock assessment including socioeconomic optimum fishing strategies were explored using a simulation model under 3 possible scenarios as management targets. The fishing strategies were simulated by changing fishing mortality and the age of first catch. It is expected that these results will emerge in proposals for the management of the spiny lobster fishery in the study area.

Key words: Rocky shore, California spiny lobster, Baja California, stock assessment, simulation

\section{INTRODUCTION}

Kelp bed forests represent some of the most conspicuous and well-studied marine habitats. These diverse and productive systems derive most of their habitat structure and available energy (fluxed carbon) from the kelp, which together with their associated communities, are features typical of temperate coast (Graham et al. 2007). Throughout its geographic range, a wide variety of factors such as hydrodynamic forces, grazing, substrate stability, light, ocean temperature and nutrient availability, play important roles influencing the giant kelp distribution and abundance (Edwards 2004).

The richness and abundance of species in this area is related to the prevailing physical and chemical conditions determined by the interaction of two sea current systems. The California
Current, which transports water from the subarctic Pacific to the Equator and a counter current of tropical origin, penetrating the tropical north Pacific, near the coast; when mixed, produce a temperate-tropical transition zone (Guzmán del Proó et al. 1991, Lluch-Belda 2000, Casas-Valdez 2003, Guzmán del Proó et al. 2003, Ponce-Díaz et al. 2003). The water of the California Current is characterized by low temperature (14$16^{\circ} \mathrm{C}$ ), constant salinity (33.5 to 33.8), high values of dissolved oxygen, and a continuous supply of nutrients (Hemingway 1979, Durazo et al. 2010, Gaxiola-Castro et al. 2010).

Changes in global and regional climate regimes are expected to affect the Baja California kelp forest communities. Kelp have limited depth and temperature ranges; as sea level and sea 
surface temperature (SST) rise with global warming, kelp community distribution be modified according to subsequent changes in substrate distribution (rocky reef) and productivity. This shift coincided with changes in total biomass of kelp associated species, such as abalone, turban snails, sea urchin and others benthic species (Graham 2004). If sea surface temperature (SST) continued higher, the southern limit of kelp distribution is expected to move further north along the Baja and southern California coast, depending on the magnitude of change in SST (Edwards \& Hernández-Carmona 2005). One of the most important large-scale perturbations impacting this coastal ecosystem is the El Niño-Southern Oscillation, event that transfers energy to mid and high latitudes and thereby alters oceanographic conditions (Edwards 2004), and therefore the kelp forest ecosystem.

The kelp forest located along the occidental coast of Baja California peninsula sustains important benthic fisheries of high commercial value as abalone and lobster, among others. The California spiny lobster (Panulirus interruptus Randall, 1840) is distributed in waters off California and the western Baja California peninsula. In Mexico, is exploited along the coast of the Baja California peninsula to northern Bahia Magdalena. Off the west central Baja California peninsula, there is a welldeveloped fishery (Fig. 1) that yields $>80 \%$ of the catch of the Mexican Pacific spiny lobster, approaching up to 2,000 tons (t) in 2003, with a value of USD> 26 Million, and providing jobs to about 1,160 fishers (Chávez \& Gorostieta 2010).

The study area is located in the center of the lobster fishery zone, ranging from Punta Abreojos to Sebastian Vizcaino Bay (Fig. 1), region with the highest abundance of the lobster Panulirus interruptus (Vega \& Lluch-Cota 1992, CastañedaFernández de Lara et al. 2005). Therefore, the purpose of the present paper is to investigate the most likely causes of higher concentration of the spiny lobster $P$. interruptus stock biomass in the study site, as well as to evaluate the fishery from the biological and socio-economic points of view, in order to propose options for its management and were explored possible effects of environmental variation on recruits and adults population of the red spiny lobster with interannual, decadal climate indices, and others. Another consideration to be made is the apparent discrepancy between a previous assessment (Chavez \& Gorostieta 2010) and this paper; so we explored here the most likely causes of those differences.

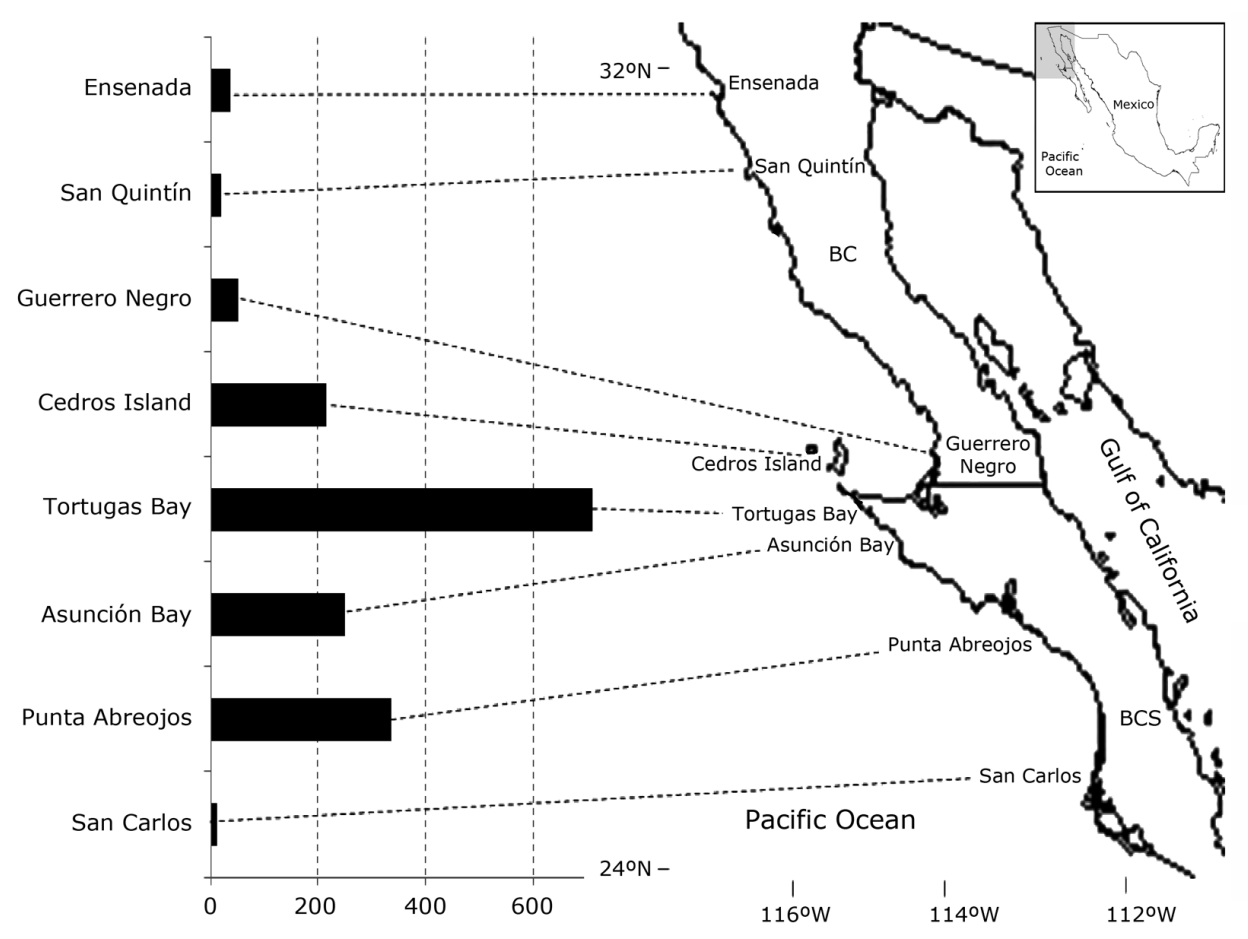

Figure 1. M ain landing sites of the California spiny lobster along the Baja California peninsula. M ean catch (t) values for the years 2006-2012 / Principales sitios de captura de langosta roja a lo largo de la península de Baja California. Valores medios de la captura (t) para los años 2006-2012 


\section{Materials AND METHODS}

\section{The EFFECT OF CLIMATE}

With the aim to explore possible effects of climate on biological systems, the interannual and decadal climate indices were utilized, the multivariate data index El Niño-La Niña (MEI) ${ }^{1}$ the data of the Pacific Decadal Oscillation index (PDO) ${ }^{2}$ proposed by Mantua et al. (1977); the database of the North Pacific Gyre Oscillation index (NPGO) ${ }^{3}$ by Di Lorenzo et al. (2009); the Southern Oscillation index (SOI $)^{3}$, and the upwelling index data. The time series of recruits and adults of Panulirus interruptus obtained from FISMO (Chávez 2005, 2014) was also compared with indices of 3 climate cycles and the upwelling index ${ }^{4}$, known to affect oceanographic conditions in Bahia Asunción area. By convention, positive anomalies in PDO represent warmer, nutrient-poor conditions in Asunción Bay, while positive anomalies of the NPGO represent increased upwelling, nutrient, and chlorophyll $a$ levels. Thus positive anomalies of the upwelling index represent an increase of chlorophyll $a$, and an increase of primary productivity and secondary production.

Table 1. Spearman correlation coefficient $(r)$ and statistical significance value (P) amongst time series (1950-2012) of recruits and adults of Panulirus interruptus with climatic indices Pacific Decadal Oscillation index (PDO), upwelling index (UPWELL), Oscillation North Pacific Gyre index (NPGO), Southern Oscillation index (SOI), and Multivariate data index El Niño-La Niña (MEI) / Coeficiente de correlación de Spearman ( $r$ ) y significancia estadística (P) entre las series de tiempo (19502012) de reclutas y adultos de Panulirus interruptus con: el índice de Oscilación el Pacífico (PDO), índice de surgencias (UPWELL), índice de Oscilación del Giro del Pacífico Norte (NPGO), índice de Oscilación del Sur (SOI) y el índice Multifactorial El Niño-La Niña (MEI)

\begin{tabular}{lrr}
\hline & \multicolumn{1}{c}{$r$} & \multicolumn{1}{c}{$P$} \\
\hline Recruits $v s$ & & \\
PDO & -0.160 & 0.213 \\
UPWELL & -0.232 & 0.0691 \\
NPGO & -0.272 & 0.0323 \\
SOI & -0.471 & 0.00013 \\
MEI (1968-2012) & 0.175 & 0.247 \\
Adults $v s$ & & \\
PDO & -0.104 & 0.421 \\
UPWELL & -0.252 & 0.0480 \\
NPGO & -0.261 & 0.0406 \\
SOI & -0.485 & 0.000075 \\
MEI (1968-2012) & 0.139 & 0.361 \\
\hline
\end{tabular}

With the aim to establish possible relations between individuals and climate, the Spearman correlation coefficient $(r)$, as a measure of correlation or interdependence association between two continuous random variables was tested (Table 1). The coefficient ranges from -1 to +1 , showing negative or positive association respectively, 0 means no correlation but not independence (Spearman 1904). This nonparametric measure of correlation is robust to outliers and has a high statistical efficiency (Croux \& Dehon 2010).

\section{THE FISHERY}

The population parameters plus the catch data were analyzed with the aid of a simulation model, implemented in the semiautomated, age-structured simulation model FISMO (Chávez 2005, 2014). The spiny lobster stock was assessed using catch data from 1950 to 2012 (SAGARPA 2013). Trends in the fishing mortality $(F)$ over time and the estimates of the stock biomass were examined. Changes in abundance over time were determined using the catch data in metric tons $(t)$. The population parameter values were taken from several authors and are indicated in Table 2. Fishing scenarios were based on the $F$ and the age of first catch $(t c)$ at the maximum sustainable yield level $\left(F_{M S Y}\right)$, the maximum economic yield level $\left(F_{M E Y}\right)$, and the $F$ level producing the maximum profits per fisher $\left(F_{M E Y f}\right)$. These scenarios were contrasted against the current biological and socio-economic conditions of the fishery. The criteria used for evaluation of fishing scenarios were based on the $F$ and the age of first catch $(t c)$.

The age of first capture is 7 years and was maintained constant in the fitting process, but for the simulation all the $F$ and $t c$ values feasible to apply were tested in the optimizing process for designing exploitation policies.

Additionally, the maximum social value was determined in two ways, the first one is the maximum level of employment required at the MSY level or in other words, the maximum number of fishermen. The second way of the approach consists in evaluating the maximum profit per fisher. Economic and social values were the value per kilogram landed, the number of fishers per boat, the number of boats and the number of fishing days, all obtained after interviews with the boat owners during the last fishing season and later extrapolated for each year of catch data, assuming that these variables and their proportions did not change over time. All of these variables were integrated into the simulation model. Costs were obtained by adding the

\footnotetext{
${ }^{1} \mathrm{MEI}<$ http://www.esrl.noaa.gov/psd/enso/mei/> ${ }^{2}$ PDO <http://www.atmos.washington.edu/ mantua/abst.PDO.htlm> ${ }^{3} \mathrm{SOI}<$ http://www.cpc.noaa.gov/data/indices/> ${ }^{4}$ Upwelling <http://www.pfeg.noaa.gov/products/PFEL/modeled/inices/upwelling.html>
} 
Table 2. Population parameter values and equations used for the evaluation of the California spiny lobster fishery / Valores de los parámetros poblacionales y ecuaciones que fueron utilizadas para la evaluación de la pesquería de langosta roja

\begin{tabular}{ccll}
\hline Parameter & Value & \multicolumn{1}{c}{ Meaning } & \multicolumn{1}{c}{ Source, equation } \\
\hline$K$ & 0.1185 & Bertalanffy & Mean of several authors* \\
$L_{\infty}(T L)$ & 153 & Bertalanffy, cm & Mean of several authors* \\
$W_{\infty}(g)$ & 3,847 & Live weight-Bertalanffy & This paper \\
$t o$ & 0.28 & Years-Bertalanffy & Mean of several authors \\
$a$ & 0.085 & Length - weight & Mean, after several authors \\
$b$ & 2.8 & Length - weight & Mean, after several authors \\
$W$ & ---- & Length - weight, g & $\mathrm{a}^{*} L^{\mathrm{b}}$ \\
$t c$ & 7 & Age of 1st catch & This paper \\
$t m$ & 5 & Years & Maturity age. This paper \\
$M$ & 0.1778 & Instantaneous rate & Jensen (1996, 1997) \\
$F_{M S Y}$ & 0.25 & $F$ at the MSY & \\
$E_{m a x}$ & 0.5845 & $E$ at $F_{M S Y}$ & $\mathrm{~F}_{\text {MSY }} /\left(\mathrm{M}+\mathrm{F}_{\mathrm{MSY}}\right)$ \\
$a$ & $18,979,294$ & Maximum number of adults & S-R model \\
$b^{\prime}$ & 0.25 & Initial slope of S-R model & S-R model \\
\hline
\end{tabular}

* These parameter values were chosen from the values proposed by the following authors: Ayala (1973); Guzmán \& Pineda (1992); Vega et al. (1996); Vega et al. (2000); Vega (2003); Chavez \& Gorostieta (2010)

cost/boat/day times the total number of fishing days of the fleet over the fishing season. Profits were estimated as the total value of the catch minus the total costs of fishing for each year. Costs and value were linked to the catch in the FISMO simulation model (Chávez 2005, 2014), which allowed testing all of the possible exploitation scenarios. The model is based on general principles of fish stock assessment (Beverton \& Holt 1957, Hilborn \& Walters 1992), with the additional inclusion of social and economic values.

Estimates of the age composition of the catch were made after the transformation of the catch records into numbers of lobsters, and later on into their corresponding biomasses. In each case total mortality $\left(Z_{t}\right)$ was determined with the exponential decay model as

$$
\mathrm{N}_{\mathrm{a}+1}=\mathrm{N}_{\mathrm{a}} \cdot \mathrm{e}_{\mathrm{t}}^{(-\mathrm{z})}
$$

where $N_{a+1}$ is the number of red spiny lobster of age $a+1$ and $N_{a}$ is the number of lobsters of age $a$ in the reconstructed agegroups. With the use of the von Bertalanffy growth equation, the numbers per age were known, allowing the determination to their corresponding lengths as,

$$
1=\mathrm{L}\left[1-\exp ^{\left(-\mathrm{k}^{*}(\mathrm{t}-\mathrm{to})\right)}\right],
$$

$1=$ Length at age $t ;=$ Asymptotic length $;=$ Growth constant, $t o=$ Theoretical age when $1=0 ; t=$ Time (years). Then, lengths were transformed into their corresponding weights using the allometric equation,

$$
\mathrm{W}=\mathrm{a} \cdot \mathrm{L}^{\mathrm{b}}
$$

where $W=$ Total weight $(\mathrm{g})$ and $L=$ Total length $(\mathrm{cm})$. The age structure for each year was estimated assuming a constant natural mortality $(M)$. For setting the variables of the initial state, the abundance perage class $\left(N_{a, y}\right)$ was defined using the age-specific abundance $N_{a} / \Sigma N_{a}$ obtained from the equation (1). In subsequent years, the age structure was defined after the estimation of the number of one-year-old recruits. These values were used to calculate catch-at-age as proposed by Sparre \& Venema (1995) and were integrated into the FISMO simulation model (Chávez 2005, 2014) as:

$$
Y_{\mathrm{a}, \mathrm{y}}=\mathrm{N}_{\mathrm{a}, \mathrm{y}} \cdot W_{\mathrm{a}, \mathrm{y}} \frac{F_{t}}{\left(F_{t}+\mathrm{M}\right)}\left(1-e^{\left(-\mathrm{F}_{t}-M\right)}\right),
$$

where $Y_{a, y}$ is the catch-at-age $a$ of each year $y, N_{a, y}$ is the number of red spiny lobster at age $a$ in year $y, W_{a, y}$ is the weight equivalent to $N_{a, y}$. Given the established initial conditions, the values of $Y_{a, y}$ were adjusted by varying the initial number of recruits and linked to the equations described above until the condition of the following equation was fulfilled,

$$
\sum_{a}^{\lambda} Y_{\mathrm{a}, \mathrm{y}}=Y_{y(\mathrm{REC})}
$$


where $Y_{y(R E C)}$ is the yield recorded during the year $y, a=7$ years, and $t_{\lambda}=3 / K$ or longevity, where $K$ is the growth constant of the von Bertalanffy growth equation and $t_{\lambda}=25$ years. Use of the catch equation was made for each year in the time-series analysed. For the estimation of $M$, the criterion proposed by Jensen $(1996,1997)$ was adopted, where $M=1.5^{*} K$ (Table 2). Estimations of the stock biomass and the exploitation rate $E=[F /(M+F)]$ following Sparre \& Venema (1995) were made for each age-class in every fishing year analysed by the model. These values were compared to the $E$ value at the $F_{M S Y}$ level, corresponding to the maximum exploitation rate that a fishery attains before the stock is over exploited. A diagnosis of which years of the series the stock was under or over exploited was then made, providing an easy way to recommend either a further increase or decrease of $F$.

Annual cohort abundance $\left(N_{a, y}\right)$ coming from ages older than age-at-maturity ( $t m=5$ years) were used to estimate the abundance of adults $\left(S_{y}\right)$ over the each year, whereas the abundance of the one-year-old group was used as the number of recruits $\left(R_{y}\right)$. The stock-recruitment relationship was evaluated by using the Beverton \& Holt (1957) model in the form,

$$
R_{\mathrm{y}+1}=\frac{\mathrm{a}^{\prime} \mathrm{S}_{o} S_{y}}{S_{y}+\mathrm{b}^{\prime} \mathrm{S}_{o}}
$$

where $R_{y+1}$ is the number of one-year-old recruits in year $y+1$, $S_{y}$ is the number of adults in year $y, S_{o}$ is the maximum number of adults in the population, and $a$ ' and $b^{\prime}$ are parameters modified from the original model where a' is the maximum number of adults and $b$ ' is the initial slope of the recruitment line. The values of the parameters used as input are shown in Table 2.

The spiny lobster fishery along the Baja California peninsula is a trap-based activity, where traps are the only authorized means of exploitation. According to data of our interviews, the average catch per fisher during a fishing season is $1,130 \mathrm{~kg}$, and they sell their landed whole lobster for \$27.00 USD per kilo. No previous data providing information on this topic has been published.

Additionally, we describe some oceanographic features, examined by other authors, as important information that possibly explain their influence as ecological driving factors which may explain their role on the lobster biology and in support to the fishermen's statements.

\section{THE EXPLOITED STOCK}

Parameter values used as input and equations are shown in Table 2. The socioeconomic analysis of the fishery was made through the explicit consideration of the costs of fishing per boat per fishing day, the number of boats, the number of fishermen per boat, and the number of fishing days during the fishing season. All of these variables affect the costs of the activity.

The value is the price at the dock of the spiny lobster landed; the profits, which are the difference between the costs and the value, is known, and the value (the Benefit) divided by the Cost is the $\mathrm{B} / \mathrm{C}$ ratio. In the simulation, the costs of fishing and catch value were assumed to be constant over time. The information of the 2008 fishing season allowed us to reconstruct the economic trend of the fishery.

\section{Results}

\section{The ECOSYSTEM FRAMEWORK}

Despite in these characteristics of water masses may reside the explanation of differences in stock numbers, a low but significant correlation between the number of recruits and the number of adults with the Southern Oscillation Index (SOI) was found, as seen in Figure 2 A, B. Time series showed oscillations over time but with decreasing trends, when were compared to inter annual and decadal climate indices. Negative correlations were found with the SOI $r=-0.47(P<0.0001)$ for recruits, and $r=$ $-0.48(P<0.0001)$ for adults and presented graphically (Fig. 2 $\mathrm{A}, \mathrm{B}$ ) as anomalies of the number of individuals (recruits and adults) with the SOI. Correlations with others climate indices were not significant (Table 1).

\section{Stock ASSESSMent AND DIAGNOSIS OF THE FISHERY}

The model was fitted to 62 years of catch data. Fit occurred once catch records and simulated yield were the same year by year (Fig. 3); therefore, all variability was assumed to be caused by fishing mortality. The assessment of the stock indicates that the catch has been essentially stable, excepting the last 15 years, when it displayed a clear increasing trend, reaching its maximum in 2011 with 2,270 t, although this trend begun since 1982, when $1,135 \mathrm{t}$ were caught. By contrast, the stock biomass has declined since 1991 when it was $22,874 \mathrm{t}$ as consequence of the fishing intensity and decreasing to $13,988 \mathrm{t}$ in 2012 . This may be interpreted as a warning sign, suggesting the need to control fishing effort.

Fishing intensity was evaluated through the variables $F$ and $E$, displayed in Figure 4, whose values were estimated through the same time scale as the catch. According to the trends, the figure showing an oscillating but gradual increase in fishing pressure for approximately three decades. However, these trends suggest that the stock has been under exploited excepting the last two years, when the $F$ and the $E$ exceed the lines $F_{M S Y}$ 


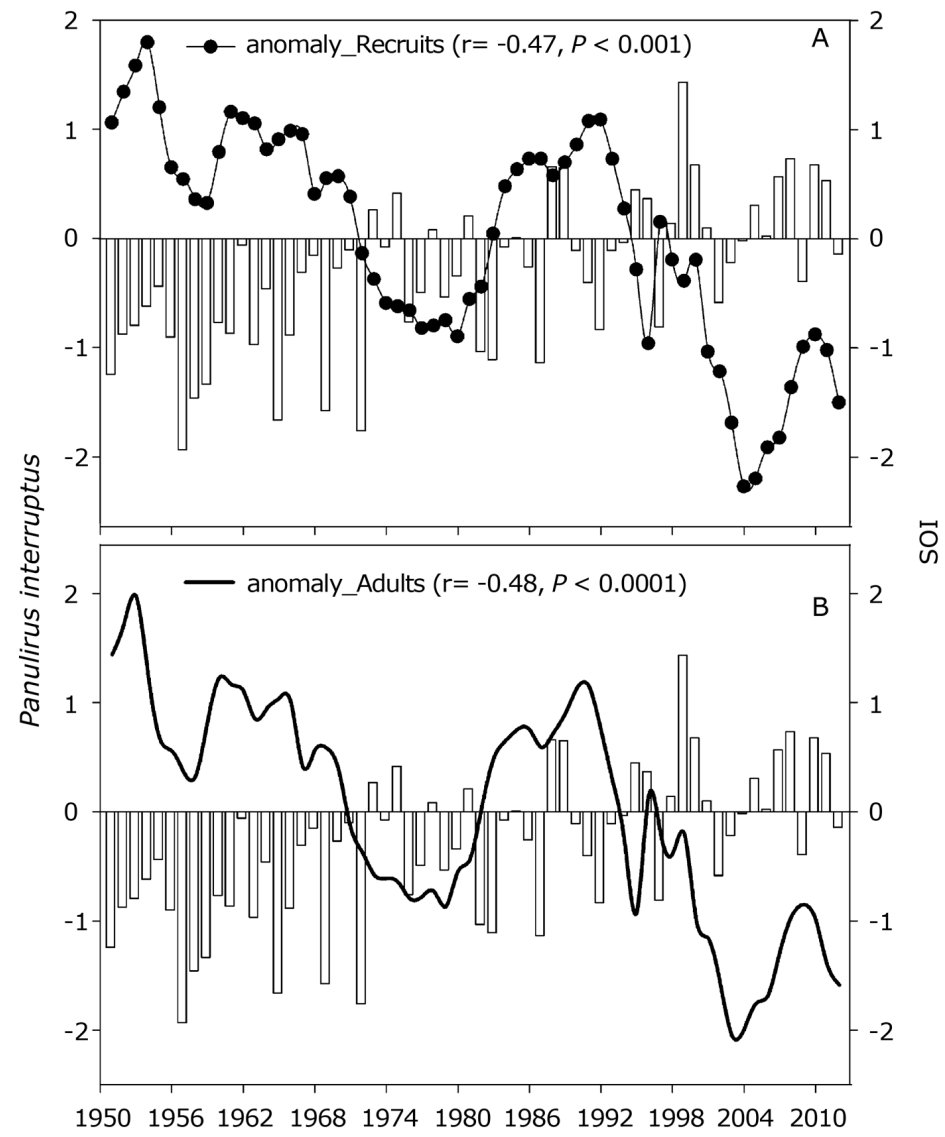

Figure 2. Effect of climate variability expressed by the Southern Oscillation Index (SOI) on the number of recruits and the number of adults of the west coast of the central Baja California peninsula. Correlations are low but significant / Efecto de la variabilidad del clima expresado mediante el índice de Oscilación del Sur (SOI) sobre el número de reclutas y el número de adultos en la costa oeste central de la península de Baja California. Las correlaciones fueron bajas pero significativas

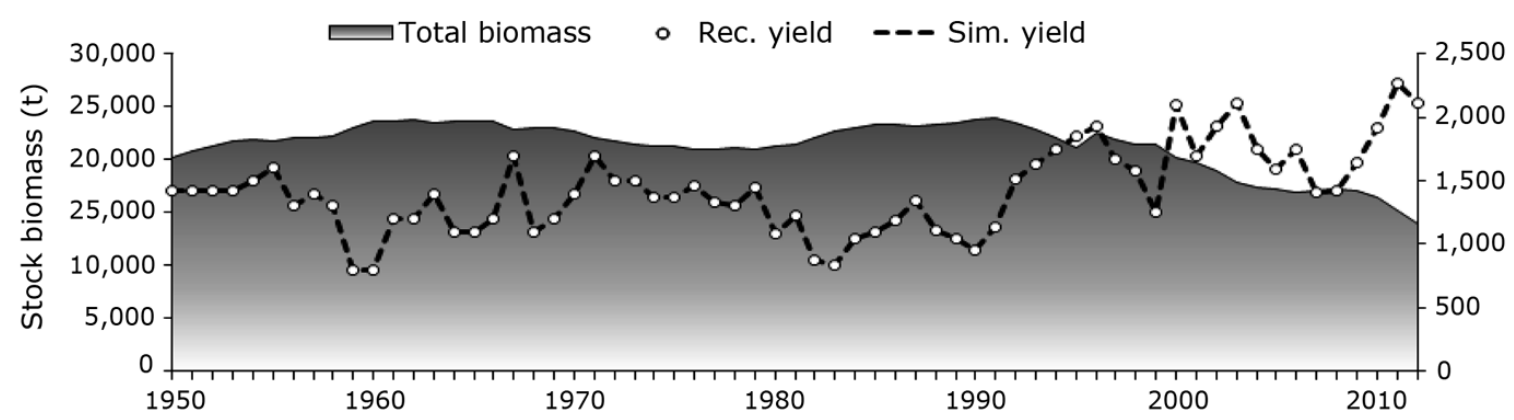

Figure 3. M odel fitted to the catch data series of the California spiny lobster exploited in M exican waters for the years 1950-2012. The catch biomass shows an increasing trend and the stock a decline since 1991. Rec., Records and Sim., simulated / Modelo de simulación alimentado con la serie de datos de la captura de la langosta roja explotada en aguas mexicanas con datos del período 1950-2012. La biomasa de captura muestra una tendencia al incremento y la biomasa del stock en un descenso a partir de 1991. Rec., Registros y Sim., simulación 


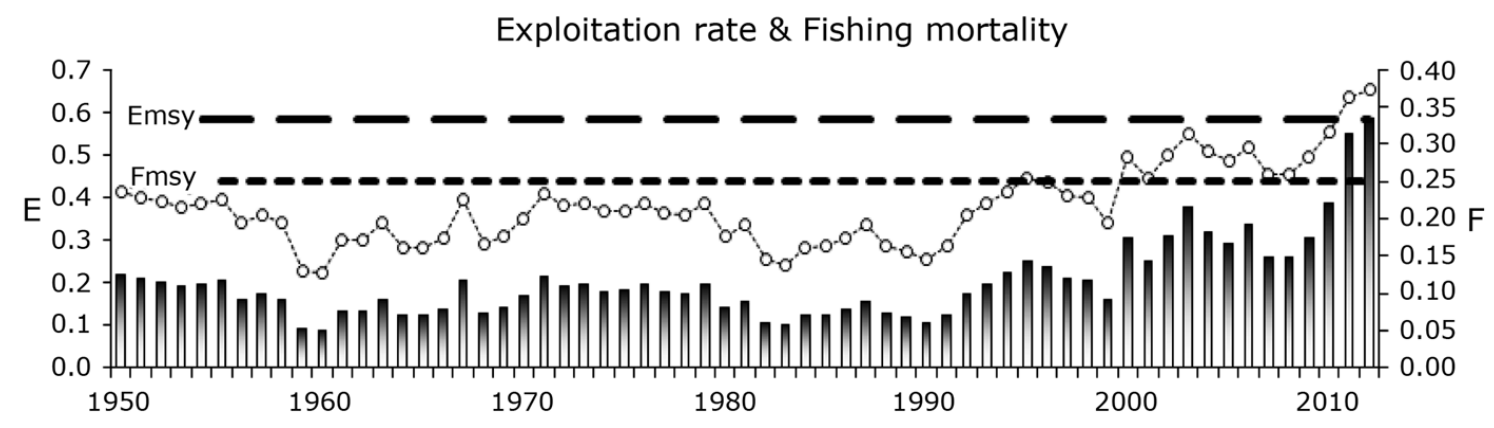

Figure 4. Trend of the $F$ (fishing mortality, bars) and $E$ (exploitation rate, dotted line) variables, as a step for the diagnosis of the California spiny lobster fishery. In both cases, these variables display a stable trend until the year 1983, when they began to grow. However, the stock has been underexploited throughout all this period, excepting the last two years / Tendencias de $F$ (mortalidad por pesca, barras) y $E$ (tasa de explotación, línea de puntos), como etapas para el diagnóstico de la pesquería de langosta roja. En ambos casos, las variables muestran una tendencia de estabilidad hasta el año 1983, cuando comienzan a incrementar. Sin embargo el stock ha sido subexplotado durante todo este periodo, excepto los dos últimos años

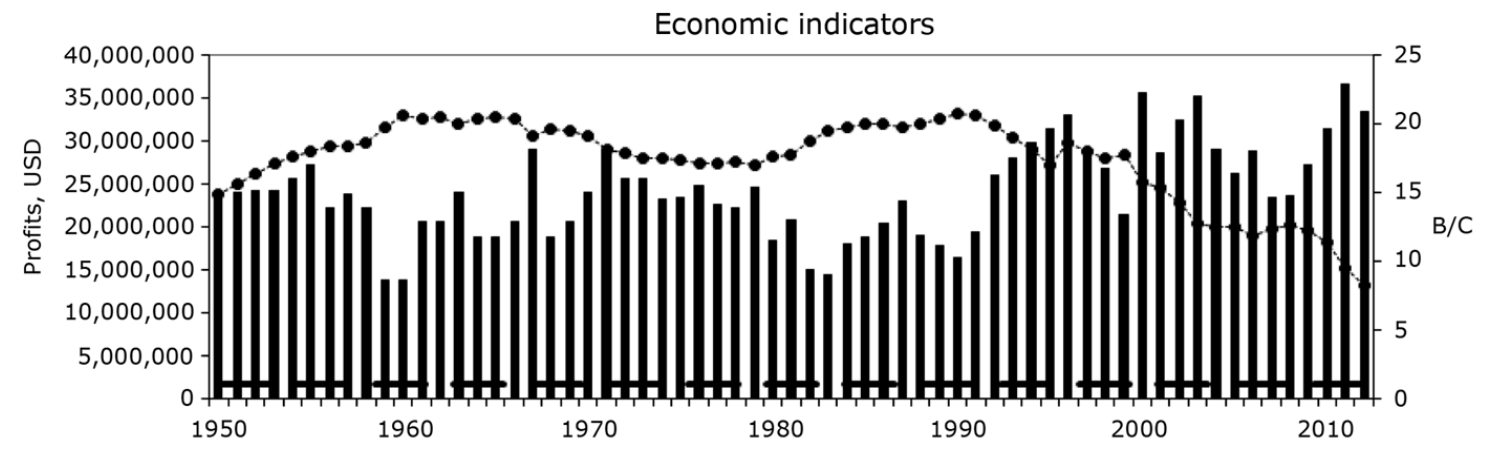

Figure. 5. Profits (bars) and Benefit/ Cost ratio (B/C, dotted line) of the California spiny lobster fishery of west Baja California, a profitable activity. The economic equilibrium level is shown as a horizontal dotted line / Utilidades (barras) y razón Beneficio/ Costo (B/C, línea de puntos) de la pesquería de langosta roja, una actividad rentable. El nivel de equilibrio económico se muestra como una línea de rayas horizontal

and $E_{M S Y}$, or in other words, the threshold of over exploitation (Fig. 4). The oscillation over time might be a result of a climatic effect, as shown in Figure 2.

The economic performance of the fishery is indicated in Figure 5, where a representation of the profits and the $\mathrm{B} / \mathrm{C}$ ratio is displayed, as well as the economic equilibrium level, when benefits and costs are the same. The profits, represented by bars, indicate that this is a profitable fishery, where most fishing seasons have profits above USD \$20 Million, reaching higher values through the last two decades. This condition seems to be a consequence of the high yields obtained after 1995 . However, these benefits had as consequence, a reduction in the economic efficiency of fishing activity, here indicated by the $\mathrm{B} / \mathrm{C}$ ratio, which despite being high during most years, display a consistent decline trend since the last two decades, attaining a value still high in 2012, of 7 times de cost of fishing (Fig. 5). It is remarkable to find out that here, as in many other fisheries, the combination of population parameter values and economic variables may impose constrains to the exploitation as seen in this fishery, in years when stock is under exploited, which without any other consideration, suggests that more effort could be addressed to achieve higher yields. However, when economic variables are taken into account, it is evident that beyond certain level of fishing effort, the fishery will stop being profitable, leading to economic crisis, because fishing pressure makes the exploitation more expensive, approaching the level to become unprofitable, as seen in Figure 6 A, B. 
A

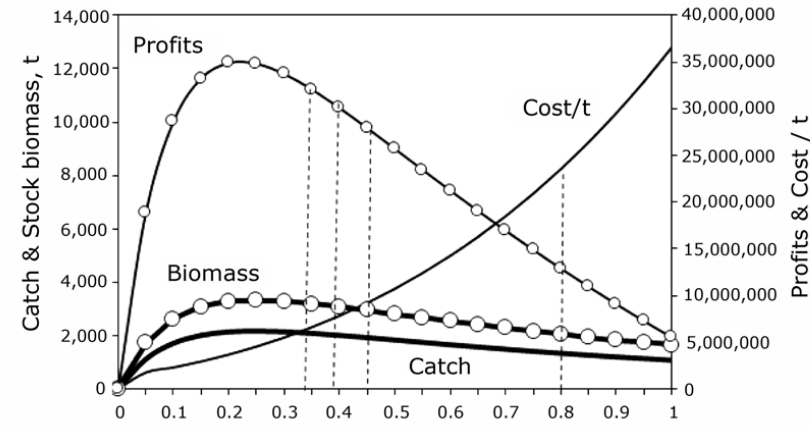

B

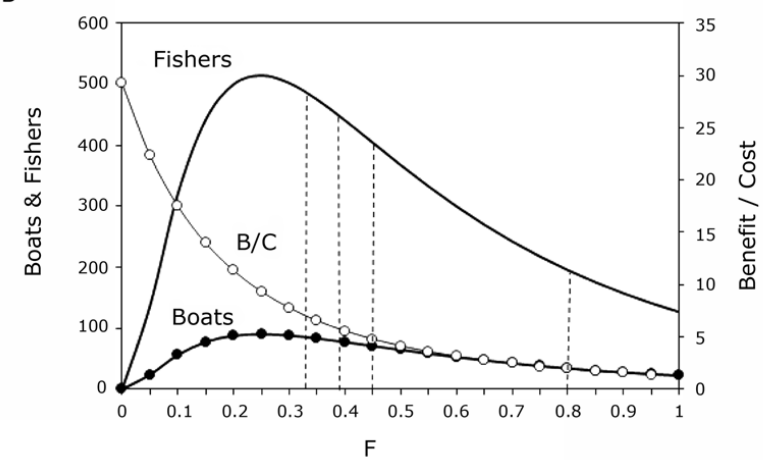

C
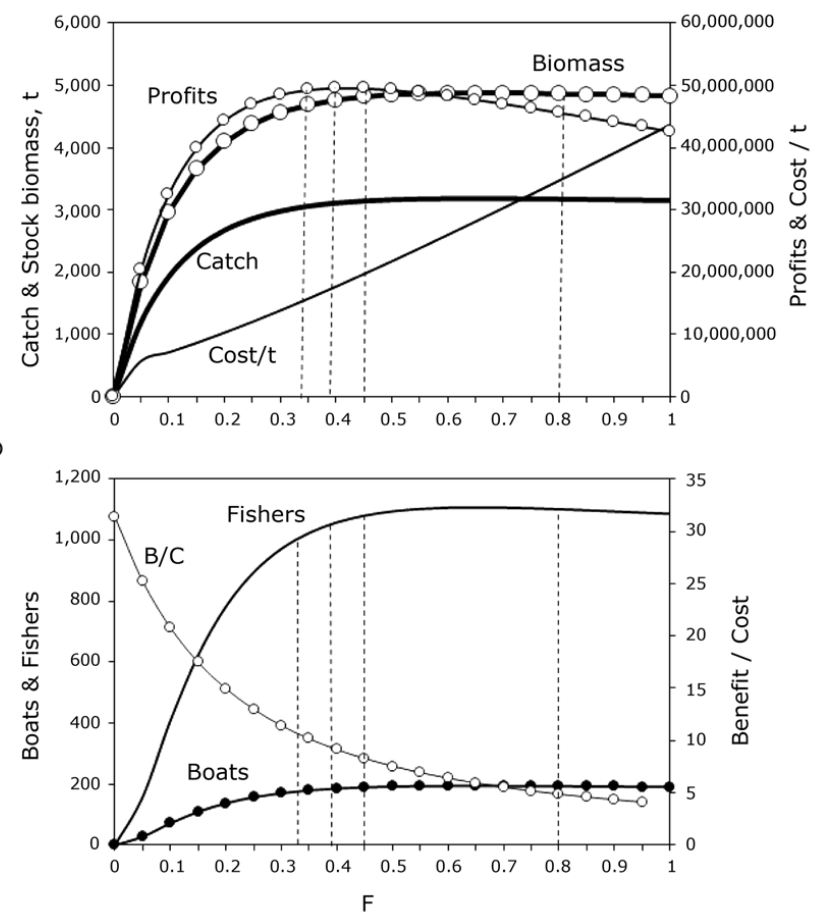

Figure 6. Stock response of the spiny lobster fishery of the Baja California peninsula, show ing the potential yield and potential profits, together with the stock biomass and the cost per $t$ caught (A), and the number of fishermen, boats, and B/C ratio (B) as a function of the fishing mortality (F). Maximum profits (MEY) are attained at a lower level of $F$ than the one required for the maximum yield (M SY). The maximum number of fishermen and boats reach their maximum at the same F value as the MSY. The maximum B/ C ratio is found at the lowest value of Fand declines monotonically with a higher fishing intensity. Four vertical lines indicate the fishing scenarios, but only the one at $F=0.33$ corresponds to the left-side figure. At $F=$ 0.39 , the MEY per fisherman; at $F=0.45$, the line of the $M E Y$ level is displayed; the current condition of the fishery is at $F=0.5$; and on the right side, the line at $F=0.8$ indicates the $M$ SY level. The scenario of the current condition is found with $t c=7$ in $A$ and $B$ at the left side; the three other scenarios correspond to tc $\mathbf{8}$ and their trends are shown in C and D / Respuesta de la población de langosta roja, donde se muestran el rendimiento y las utilidades potenciales, junto con la biomasa del recurso, y el costo por t capturada (A); además, el número de pescadores, de embarcaciones y la razón $B / C(B)$, todas en función de la mortalidad por pesca ( $F$ ). Las utilidades máximas (MEY) se alcanzan en un nivel de $F$ más bajo que el que requerido para el rendimiento máximo (MSY). El número máximo de pescadores y el de embarcaciones se alcanzan en el mismo valor de $\mathrm{F}$ que el rendimiento (MEY). El valor más alto de la razón $B / C$ se encuentra en el valor más bajo de $F$ y disminuye uniformemente conforme aumenta la intensidad de pesca. Cuatro líneas verticales indican los escenarios de pesca, pero solo el de $\mathrm{F}=0,33$ corresponde a la figura de la izquierda. En $F=0,39$, el MEY por pescador; en segundo lugar, con $F=0,45$, la condición actual de la pesquería, a la mitad se indica el nivel del $M E Y$ (Rendimiento Económico Máximo) con una $F=0,5$; y a la derecha, con $F=0,8$, el nivel del MSY (Rendimiento Máximo Sostenible). El escenario de la condición actual se encuentra a una edad de primera captura $t C=7$, en $A$ y $B$ ) a la izquierda; los otros tres escenarios corresponden a tc $=8$ y sus tendencias se muestran en $C$ y $D$

\section{Management SCEnarios}

Once the model is fitted to catch data of the red spiny lobster, it allows simulating fishing scenarios by applying the catch equation to the reconstructed age structure and assigning $F$ values (Figs. 6 A to D).

Numerical output provides a convenient solution to generate fishing scenarios and to propose management regulations; for comparison the performance of some of the output variables, the condition of the 2012 fishing season is the current condition used as reference. By keeping the current $t c=7$ years or a length of $25.3 \mathrm{~cm}$, the output produces a line describing potential yield as a function of $F$, indicating which is the fishing intensity producing the current yield $(1,725 \mathrm{t})$. The $M S Y(3,709 \mathrm{t})$ is found at $F=0.8$ and $t c=8$ years. Two other management options are $F_{M E Y,}$ at the combination of $F(=0.80)$ and $t c(=8$ or 27.6 $\mathrm{cm})$ producing the highest catch of 3,709 $\mathrm{t}$ and profits = USD $\$ 58,976,554$. The last scenario examined, is the Maximum Economic Yield per fisher, whose reference values are $t c=8$ years, $F=0.39, C=3,602$ t, and Profits/Fisher $=\$ 127,827$. Numerical data describing these scenarios are shown in Table 3. 
Table 3. Management scenarios of the red spiny lobster of the fishery at the west central coast of the Baja California peninsula, showing numerical values of Profits and B/C ratio shown on Figure 5. Other additional 16 variables are also presented / Escenarios de gestión de la pesquería de langosta roja en la costa oeste central de la península de Baja California, se muestran los valores numéricos de las variables Utilidades y la razón Beneficio/Costo (B/ C) presentadas en la Figura 5. También se muestran los valores de otras 16 variables

\begin{tabular}{lcccc}
\hline Indicators & Current & & & \\
& 2012 & $\mathrm{~F}_{\text {MSY }}$ & $\mathrm{F}_{\text {MEY }}$ & Fmey/fisher \\
\hline Stock Biomass & 15,564 & 17,524 & 21,416 & 22,569 \\
F (/yr) & 0.3340 & 0.80 & 0.45 & 0.39 \\
Exploitation Rate & 0.58 & 0.82 & 0.72 & 0.69 \\
CATCH & 1,725 & 3,709 & 3,652 & 3,602 \\
C.V. & 21.14 & 21.14 & 21.14 & 21.14 \\
VALUE & $31,050,000$ & $66,759,232$ & $65,740,405$ & $64,836,319$ \\
DAYS & 41,092 & 107,363 & 60,392 & 52,753 \\
Direct Jobs & 87 & 488 & 474 & 461 \\
BOATS & 41 & 242 & 234 & 228 \\
CAPACITY & 87,790 & 115,453 & 115,453 & 115,453 \\
Days/Boat/Season & 180 & 100 & 100 & 100 \\
Costs/Boat/day & 112 & 112 & 112 & 112 \\
Total Costs/Boat & 20,160 & 11,200 & 11,200 & 11,200 \\
TOTAL COSTS & $4,602,317$ & $12,024,624$ & $6,763,851$ & $5,908,335$ \\
Costs/Catch & 2,668 & 3,242 & 1,852 & 1,640 \\
B/C & 6.7 & 5.6 & 9.7 & 11.0 \\
PROFITS & $26,447,683$ & $54,734,608$ & $58,976,554$ & $58,927,984$ \\
PROFITS/BOAT & 642,607 & 226,434 & 251,604 & 258,457 \\
PROFITS/FISHER & 302,904 & 112,058 & 124,474 & 127,827 \\
Age of 1st CATCH & 7 & 8 & 8 & 8 \\
Total length, cm & 25.30 & 27.6 & 27.6 & 27.6 \\
\hline
\end{tabular}

\section{Discussion}

\section{THE ECOSYSTEM}

The study area can be seen as the most productive for the two main fisheries, abalone and red spiny lobster. This consideration leads to expect that the fishing grounds should be in the core of the highest regional peaks of productivity. However, studies on the areas acknowledged as Biological Activity Centres (BACs) of the Mexican Pacific (Lluch-Belda 2000, Lluch-Cota \& Teniza-Guillén 2000, Morales-Zárate et al. 2000, MuñozMejía et al. 2000), suggest that the fishing grounds lay between contiguous BACs, but none of the latter ones is directly overlapped to the study area. Therefore, a different explanation is suggested by Arreguín-Sánchez (2000) and Lluch-Cota \& Teniza-Guillén (2000), who state that the BACs play a role of sources of productivity exporting the primary productivity to their marginal zones, like Tortugas Bay, where it is used by primary consumers; the two exploited stocks have their centres of the highest fisheries production there. The possibility that the concentration of human beings could be another reason must be discarded, because based on their isolation from other human activities, the most likely reason supporting the idea that the fishing village exploiting these resources exists is because they are close to the fishing grounds, not the other way around. The intertidal habitat is used by juvenile lobsters and for this reason it is particularly vulnerable, due to its proximity to anthropogenic activities, human impacts and environmental processes (Robles 1997, Withy-Allen 2010).

In addition, it seems to be correlation between the settlement of lobster post larvae and the commercial catch, with a fiveyear delay (Arteaga-Ríos et al. 2007), associated to the influence ofEl Niño Southern Oscillation. Evidence of the impact of the SOI event was previously demonstrated by Chávez \& Castro-Ortiz (2010a, b), and its effect is confirmed here. It is remarkable to find out that the number of recruits as well as the number of adults display a consistent decline over more than 60 years, leading to conclude that in the long term, the climate has stronger effect on the stock biomass of this and other 
species. By contrast, in short term, the fishing pressure may have a more evident effect, and sometimes, fishing intensity may have a synergistic impact with that of the climate, accelerating a decline or an increase. However, this seems to be not the case of the spiny lobster stock being analysed.

Temperature has a decisive influence on the distribution, physiological processes, metabolism and reproduction of marine organisms (Lindberg 1955, Ayala et al. 1973, Vega et al. 1991, Vega 2003). The event El Niño Southern Oscillation is one of the most important factors that determine climate variability and ecosystem structure within the area of influence of the California Current System and its impact defines the reproductive success of many species. Its effect on the spiny lobster stock is evident.

However, we could not find a more detailed evidence than the SOI index to explain which factors may be responsible for higher or lower catches in the study area, although it sounds like a logical explanation to expect that this aspect of local characteristics of oceanic current may have influenced the concentration of post larvae increasing recruitment and enhanced catch in the central portion of the study area.

Larval retention and transport northward increases in years when El Niño events occur; during these periods, the Ekman transport offshore is reduced and the warm tropical waters penetrate northward along the coast of Mexico to southern California (Pringle 1986, Pollock 1992). Seasonal upwelling caused by wind, incorporates subsurface nutrient-rich cold water into the surface along the coast when it is known that the coastal zone is significantly more productive than the rest of the oceans, especially in areas of upwelling along the eastern margins of the great eddies. It has been shown that a very significant portion of total productivity of the system is provided by the advection of the California Current, itself, especially that related to the abundance of macro zooplankton (Lluch-Belda 2000, Phillips $\&$ McWilliams 2011). Pringley (1986) stated that low temperatures tend to delay the development process together with ocean dynamics. Conversely, warm temperatures during El Niño events promote early maturity of adults, and significantly accelerating embryonic development (Phillips \& Sastry 1980, Pollock 1992, Vega 2003, Ortuño-Manzanares 2010).

Our approach to explain these differences in catch along a latitudinal gradient, did not allow us to demonstrate which environmental variables are the responsible ones, but the SOI is a good indicator that a complex influence of climatic variability drives the trends in the survival of recruits with different intensity and what we see is just an instantaneous image of a continuous process through evolutionary process.

\section{THE FISHERY}

The reason why the effect of the climate just mentioned is not quite clear is explained by the fact that the maturity age is 5 years and the age of first catch is 7 years. This circumstance allows two years of young adults to reproduce and replace the stock with enough recruits contributing to maintain a steady population over time and for this reason, a surplus production of recruits compensates the declining trend induced by the climate.

Sensitivity of the model FISMO, to a range of parameter values was tested after being translated into its Matlab version (Neilson 2010a, b), finding that it provides higher resolution of $F_{M S Y}$ estimates, indicating that the California portion of the spiny lobster fishery is stable.

The fishery of the west coast of Baja California is a profitable activity and the stock biomass indicates a stable trend through the late eighties, followed by a decline since the early nineties till the last year of data series leading to a condition of over exploitation through 2011 and 2012. Conversely, the catch displayed an increasing intensity since the middle eighties, and this is interpreted as the reason of the decline of the stock biomass. With the intention to explain the apparent misinterpretation of the condition of the fishery which was diagnosed as overexploited between 2003 and 2008 (Chávez $\&$ Gorostieta 2010), the model inputs used in that paper were critically examined, finding two possible explanations, in first place, the to parameter value that was used is negative; secondly, the age of first catch is 4 years for males and 7 for females, as stated by Vega (2003), this may be confusing and the use of a common growth model for both sexes introduces considerable bias. Depending on the age used as input, the stock biomass estimated by the model may produce big differences and therefore could lead to a misinterpretation of the diagnosis; in the present paper the $t c$ value used also was 7 years, because at that age is when females are mature. Here, the to value used as input has a positive sign, based on the consideration that the von Bertalanffy growth model describes the trend line of growth as long as the animals maintain the same shape, and let us remind that the spiny lobster has a long lasting larval stage of 7-9 months drifting in the sea and its shape is considerable different than that of the benthic phase; this may imply big difference in the estimation of the stock biomass. Another significant difference between this and the paper by Chávez \& Gorostieta (2010) was found in the value of the parameter $b$ of the allometric equation, in that paper a value of $b=3$ was used as an approximation, and in this one the value of 2.8 was applied; this difference implies that with $b=3, W_{\infty}=7,135 \mathrm{~g}$ and when 
$b=2.8$, the asymptotic weight is only $3,847 \mathrm{~g}$, producing a big difference in the stock biomass. This difference implies that for a given catch, two very different $F$ values would be required. These differences emphasize the importance of applying the most accurate parameter values to obtain unbiased estimation of the stock biomass. Many other scenarios can be created and they can be conceived by the imagination, but constrained by its practical application. So far, the ones evaluated here are the most evident and with better chances to be adopted according to the circumstances and the political will in the moment when they could be applied.

Finally, it is necessary to update the information enabling to review and adopt the most accurate parameter values according to the most recent data available, allowing reduction of any bias and assessing exploited stocks more closely to reflect regulatory mechanisms more appropriate to the biological characteristics of the species. This way, it is expected that it will be achieved the design of a more suitable management plan for the California lobster fishery.

\section{ACKNOWLEDGEMENTS}

To anonymous reviewers read the manuscript and made valuable suggestions. E. Chavez holds a research grant from COFAA and EDI, IPN.

\section{LITERATURE CITED}

Arreguín-Sánchez F. 2000. Modelación de flujos de biomasa en centros de actividad biológica. En: Lluch-Belda D, J Elorduy-Garay, SE Lluch-Cota \& G Ponce-Díaz (eds). BAC Centros de actividad biológica del Pacífico mexicano, pp. 13-28. CIB-CICIMAR-CONACyT, México.

Arteaga-Ríos LD, J Carrillo-Laguna, J Belmar-Pérez \& SA Guzmán Del Proó. 2007. Post-larval settlement of California spiny lobster Panulirus interruptus in Bahia Tortugas, Baja California and its relationship to the commercial catch. Fisheries Research 88: 51-55. <doi:10.1016/ j.fishres.2007.07.007>

Ayala MY, J Pineda \& SA Guzmán Del Proó. 1973. Explotación de la langosta roja en el estado de Baja California durante la temporada 1971-1972. Análisis de la composición por tallas de la captura comercial. Serie Informativa INP/SI, pp 33-48

Beverton RJH \& SJ Holt. 1957. On the dynamics of exploited fish populations. Fishery Investigations, London, Series II 19: $1-533$.

Casas-Valdez M, E Serviere-Zaragoza, D Lluch-Belda, $\mathbf{R}$ Marcos \& R Aguilar-Ramírez. 2003. Effect of climatic change on the harvest of the kelp Macrocystis pyrifera on the Mexican Pacific coast. Bulletin of Marine Science 73(3): 545-556.
Castañeda-Fernández-de-Lara V, E Serviere-Zaragoza \& S Hernández-Vázquez. 2005. Feeding ecology of juvenile spiny lobster, Panulirus interruptus, on the Pacific coast of Baja California Sur, Mexico. New Zealand Journal of Marine and Freshwater Research 39: 425-435.

Chávez EA. 2005. FISMO: A Generalized Fisheries Simulation Model. In: Kruse GH, VF Gallucci, DE Hay, RI Perry, RM Peterman, TC Shirley, PD Spencer, B Wilson \& D Woodby (eds). Fisheries assessment and management in data-limited situations: Proceedings of the Symposium Assessment and Management of New and Developed Fisheries in DataLimited situations. Alaska Sea Grant College Program, University of Alaska Fairbanks, Anchorage, pp. 659-681.

Chávez EA. 2014. Un modelo numérico para la administración sustentable de las pesquerías. CICIMAR Oceánides 29(2): 45-56.

Chávez EA \& JL Castro-Ortiz. 2010a. Effect of global change on the fish catch off the Mexican Pacific coast. Globec International Newsletter 16(1): 52-55.

Chávez EA \& JL Castro-Ortiz. 2010b. Impacto del cambio climático sobre las pesquerías de la zona de transición cálidotemplada del Pacífico oriental mexicano. In: López-Martínez J (ed). La variabilidad ambiental y las pesquerías de México, pp. 70-83. Comisión Nacional de Acuacultura y Pesca, SAGARPA, México.

Chávez EA \& M Gorostieta. 2010. Bioeconomic assessment of the red spiny lobster fishery of Baja California, Mexico. CalCOFI Report 51: 153-161.

Croux C \& C Dehon. 2010. Influence functions of the Spearman and Kendall correlation measures. Statistical Methods \& Applications 19: 497-515.

Di Lorenzo E, J Fietcher, N Schneider, A Bracco, AJ Miller, PJS Franks, SJ Bograd, AM Moore, AC Thomas, W Crawford, A Peña \& AJ Hermann. 2009. Nutrient and salinity decadal variations in the central and eastern North Pacific. Geophysical Research Letters 36: 1-6.

Durazo R, AM Ramírez-Manguilar, LE Miranda \& LA Soto-Mardones. 2010. Climatología de variables hidrográficas. En: Gaxiola-Castro G \& R Durazo-Arvisu (eds). Dinámica del ecosistema pelágico frente a Baja California, 1997-2007, pp. 25-57. SEMARNAT - INE CICESE - UABC, México.

Edwards MS. 2004. Estimating scale-dependency in disturbance impacts: El Niño and giant kelp forests in the northeast Pacific. Oecologia 138: 436-447.

Edwards MS \& G Hernández-Carmona. 2005. Delayed recovery of giant kelp near its southern range limit in the in the north Pacific following El Niño. Marine Biology 147: 273-279.

Gaxiola-Castro G, J Cepeda-Morales, S Nájera-Martinez, TL Espinosa-Carreón, ME De-La Cruz-Orozco, E Aguirre-Hernández \& JP Cantú-Ontiveros. 2010. Biomasa y producción de fitoplancton. En: Gaxiola-Castro G \& R Durazo-Arvisu (eds). Dinámica del ecosistema pelágico frente a Baja California, 1997-2007. Diez años de investigaciones mexicanas de la Corriente de California, pp. 59-85. SEMARNAT-INE-CICESE-UABC, México. 
Graham MH. 2004. Effects of local deforestation on the diversity and structure of southern California giant kelp forest food webs. Ecosystems 7: 341-357.

Graham MH, JA Vásquez \& AH Buschmann. 2007. Global ecology of the giant kelp Macrocystis: from ecotypes to ecosystems. Oceanography and Marine Biology: An Annual Review 43: 39-88.

Guzmán del Proó SA, SR Mille-Pegaza, R GuadarramaGranados, $S$ de la Campa de Guzmán, J Carrillo-Laguna, A Pereida-Corona, J Belmar-Pérez, MJ Parra-Alcocer \& AC Luque-Guerrero. 1991. La comunidad bentónica de los bancos de abulón (Haliotis spp. Mollusca: Gastropoda) en Bahía Tortugas, BCS, México. Anales de la Escuela Nacional de Ciencias Biológicas 36: 27-59.

Guzmán del Proó SA, L Carreón-Palaú, J Belmar-Pérez, J Carrillo-Laguna \& R Herrera-Fragoso. 2003. Effects of the 'El Niño' event on the recruitment of benthic invertebrates in Bahía Tortugas, Baja California Sur. Geofisica Internacional 42(3): 429-438.

Hemingway GT. 1979. A description of the California Current ecosystem by factor analysis. CalCOFI Report 20: 164-183.

Hilborn R \& C Walters. 1992. Quantitative fisheries stock assessment. Choice, dynamics and uncertainty 2: 177-186. Chapman \& Hall, London

Jensen AL. 1996. Beverton and Holt life history invariants result from optimal trade of reproduction and survival. Canadian Journal Fisheries and Aquatic Science 53: 820-822.

Jensen AL. 1997. Origin of the relation between $\mathrm{K}$ and $\mathrm{L}_{\infty}$ and synthesis of relations among life history parameters. Canadian Journal of Fisheries and Aquatic Sciences 54: 987-989.

Lindberg RG. 1955. Growth, population dynamics, and field behaviour in the spiny lobster, Panulirus interruptus (Randall). University of California, Publication Zoological 59: 157-248.

Lluch-Belda D. 2000. Centros de actividad biológica en la costa occidental de Baja California. En: Lluch-Belda D, J ElorduyGaray, SE Lluch-Cota \& G Ponce-Diaz (eds). BAC Centros de Actividad Biológica del Pacífico mexicano, pp. 49-64. CIB-CICIMAR-CONACyT, México.

Lluch-Cota D \& G Teniza-Guillén. 2000. BAC versus áreas adyacentes: una comparación de la variabilidad interanual de pigmentos fotosintéticos a partir del Coastal Zone Color Scanner (CZVS). En: Lluch-Belda D, J Elorduy-Garay, SE Lluch-Cota, G Ponce-Díaz (eds). BAC Centros de Actividad Biológica del Pacífico mexicano, pp. 199-218. CIBCICIMAR-CONACyT, México.

Mantua NJ, SR Hare, Y Zhang, JM Wallace \& RC Francis. 1997. A Pacific interdecadal climate oscillation with impacts on salmon production. Bulletin of the American Meteorological Society 78: 1069-1079.
Morales-Zárate MV, SE Lluch-Cota, D Voltolina \& EM Muñoz-Mejía. 2000. Comparación entre zonas de alta actividad biológica en la costa occidental de Baja California: Punta Eugenia y Punta Baja. En: Lluch-Belda D, J ElorduyGaray, SE Lluch-Cota \& G Ponce-Díaz (eds). BAC Centros de Actividad Biológica del Pacífico mexicano, pp 99-110. CIB-CICIMAR-CONACyT, México.

Muñoz-Mejía E, SE Lluch-Cota, D Voltolina \& V MoralesZárate. 2000. Exploración de la capacidad predictiva de los BAC en espacio y tiempo: Punta Eugenia y el sur de California. In: Lluch-Belda D, J Elorduy-Garay, SE LluchCota \& G Ponce-Díaz (eds). BAC Centros de Actividad Biológica del Pacífico mexicano, pp. 87-98. CIB-CICIMARCONACyT, México.

Neilson D. 2010a. CDFG California Spiny Lobster Stock Assessment, Synopsis, 2 pp. California Department of Fish and Wildlife Service, Monterey. 〈https://www.wildlife.ca.gov/ Conservation/Marine/Lobster-FMP/Assessment>

Neilson D. 2010b. CDFG California Spiny Lobster Stock Assessment, 21 pp. Executive Summary and California Department of Fish and Wildlife Service, Monterey. <https:/ /www.wildlife.ca.gov/Conservation/Marine/Lobster-FMP/ Assessment>

Ortuño-Manzanares G. 2010. Larvas filosoma de langosta roja (Panulirus interruptus) durante el año 2000. En: GaxiolaCastro G \& R Durazo-Arvisu (eds). Dinámica del ecosistema pelágico frente a Baja california, 1997-2007. Diez años de investigaciones mexicanas de la Corriente de California, pp. 365-380. SEMARNAT-INE-CICESE-UABC, México.

Phillips BF \& PS McWilliam. 2011. The pelagic phase of spiny lobster development. Canadian Journal of Fisheries and Aquatic Science 43(11): 2153-2163.

Phillips BF \& AN Sastry. 1980. Larval ecology. In: Cobb JS $\&$ BF Phillips (eds). The biology and management of lobsters. Volume II. Ecology and management of lobsters, pp. 11-57. Academic Press, New York.

Pollock DE. 1992. Palaeoceanography and speciation in the spiny lobster genus Panulirus in the Indo-Pacific. Bulletin of Marine Science 51(2): 135-146.

Ponce-Díaz G, SE Lluch-Cota, JJ Bautista-Romero \& D Lluch-Belda. 2003. Multiscale characterization of the sea temperature in an area of abalone banks (Haliotis spp.) at Bahía Asunción, Baja California Sur, México. Ciencias Marinas 29(3): 291-303.

Pringle JD. 1986. California spiny lobster (Panulirus interruptus) larval retention and recruitment: a review and synthesis. Canadian Journal of Fisheries and Aquatic Sciences 43: 2142-2152.

Robles CD. 1997. Changing recruitment in constant species assemblages: implications for predation theory in intertidal communities. Ecology 78(5): 1400-1414. 
SAGARPA. 2013. Carta Nacional Pesquera. Secretaría de Agricultura, 236 pp. Ganadería, Desarrollo Rural, Pesca y Alimentación, México.

Sparre P \& SC Venema. 1995. Introducción a la evaluación de recursos pesqueros tropicales. Parte 1. Manual. FAO Fisheries Technical Paper 306/1 Rev. 1: 1-420.

Spearman C. 1904. General intelligence objectively determined and measured. American Journal of Psychology 15: 201-293.

Vega VA. 2003. Reproductive strategies of the spiny lobster Panulirus interruptus related to the marine environmental variability off central Baja California, Mexico: management implications. Fisheries Research 65: 123-135.

Vega VA \& DB Lluch-Cota. 1992. Análisis de las fluctuaciones en los volúmenes de langosta (Panulirus spp.) del litoral oeste de la Península de Baja California, en relación con el desarrollo histórico de la pesquería y la variabilidad del marco ambiental. Noviembre 1991. En: Memorias del Taller Internacional México-Australia sobre reclutamiento de los recursos marinos bentónicos de la Península de Baja California, pp. 191-212. IPN / ENCB / CICIMAR-INAPESCA, La Paz, Baja California Sur, México.
Vega VA, AJ González, QM Espinoza, CG Ortíz, MJ León, RMA Turrubiates, J Reinecke, C Singh, M Muciño, GE Michel \& AE Castro. 1991. Patrón reproductivo de la langosta roja (Panulirus interruptus) (Randall, 1840) en la costa oeste de la Península de Baja California y sus variaciones espacio temporales en relación con la regulación (veda) de su explotación, 45 pp. Informe Técnico del Instituto Nacional de la Pesca, CRIP, La Paz.

Withy-Allen KRY. 2010. California spiny lobster (Panulirus interruptus) movement behavior and habitat use: Implications for the effectiveness of marine protected areas. Thesis of Master of Science in Biology, San Diego State University, San Diego, 57 pp. 